\title{
Reviews and Propose Model for the System Dynamics in Contemporary Tendencies of Third-Party Logistics towards Business Performance in Malaysia and Thailand
}

\author{
Awoyemi Adebare Omotayo ${ }^{1}$, Mustakim Melan ${ }^{2}$, Zulkufli Aziz ${ }^{3}$, Pichit Prapinit ${ }^{4}$, Patchateeya Boonyarit ${ }^{5}$, \\ Mohamad Ghozali Hassan ${ }^{6}$

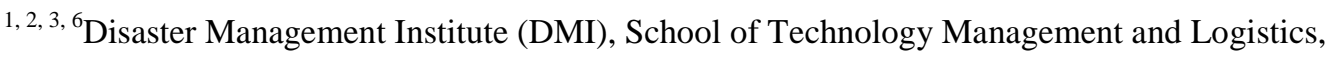 \\ College of Business, Universiti Utara Malaysia, 06010, Sintok, Kedah. \\ ${ }^{4,5}$ Policy and Planning, Loei Rajabhat University (LRU), 234 Loei Cheing Kan, 42000 Loei, Thailand. \\ simpletayo2008@yahoo.com ${ }^{1}$, mustakim@uum.edu.my ${ }^{2}$, zulaziz@uum.edu.my ${ }^{3}$, pichitprapinit@gmail.com ${ }^{4}$, \\ logistic.border.lru@gmail.com ${ }^{4}$,ghozali@uum.edu.my ${ }^{6}$
}

Article History: Received: 10 November 2020; Revised: 12 January 2021; Accepted: 27 January 2021;

Published online: 05 April 2021

Abstract: The present Third Party Logistics (3PL) service providers in Malaysia and Thailand are expending their effectiveness and efficiency in several spheres from contemporary logistics services offers towards the series of value-added services to their customers. There is a need to forecast their key performance indicators growth using a systematic approach in resource management, as their quality indicators. Hence, this paper discovers on the current propensities of 3PLs service providers in respect of issues connected with their performance, resources and quality to establish on the 3PLs indicators of resources, quality and processes. It is also sought to develop a model of systematic dynamics for internal resources and company processes optimization based on the best practices. The methodology of the research is based on literature reviews which focusing on the performance measurement, quality and resources of 3PL. Using a System Dynamics, a model of optimization and management of 3PL, the internal processes and resources were developed. This model comprises of Nine (9) segmentations, which are operations, commercial activities, administration, personnel management, procurement, quality management, Resources, Performance Measurement and Financial models. The model is indicating all areas of activities of 3PL service providers. This study proposes a new model for Third-party Logistics (3PL) performance indicators for future guidelines in related industry.

Keywords: Third Party Logistics providers, System Dynamics, key performance indicators, resources, quality management.

\section{Introduction}

The development of present Information Communication Technology (ICT), the numbers of organization specializing in logistics and transportation businesses with warehousing and storage has growing up. In order to optimize the costs of logistics and transportation which focuses on the core activities, several foreign organization and business outfits were outsource some of their logistics activities to third party logistics companies. This becomes a common practice in international business as a result with comprehensive knowledge and experiences which permits provision of logistics and transportation at minimal costs. Strong competitive advantages in several industries is considered the key factor for the development and appearance of 3PL. In this type of business atmosphere, businesses are enforced to develop new products in a continuous way and exploit the delivery procedure that is effective in the transportation of goods to the various clients. Over the period, 3PLs firms have enlarge their jobs scope of which they are to involve an expansive geographical spread and uphold a larger range of facilities for different kind of goods and services. In the light of resource-based view, firms are encouraged to establish their strategic resources to offer competitive advantage in a long-term base. The 3PLs is a business with smaller assets, brand and personnel; hence the in-house resources that relevant with the clients must be managed wisely.

\section{Background}

\subsection{The Purpose of the Study}

The aim of the study is to propose a new model in 3PLs service providers for their efficiency with customers. The model that is dynamic in nature which design resources, efficiently, measure contemporary, quality and forecast growth. Hence, the main purpose of this paper is to develop the current model of 3PL by determining on the current tendencies and businesses in relation to quality, performance and resources. Likewise, the model would also oversee on the indicators of the resources, quality and processes of 3PLs service providers. The overview of the model is to engage on the system dynamics method and offer an opportunity to maximise 3PLs processes and internal resources. 
Awoyemi Adebare Omotayo, Mustakim Melan, Zulkufli Aziz, Pichit Prapinit, Patchateeya Boonyarit, Mohamad Ghozali Hassan

\subsection{Methodology of the Study}

The methodology adopted in this paper is a systematic review through past literatures and adoption of the thinking with general models. The research is based from the suggested literature with critical thinking process. The sequence includes on the literature reviews, definition of 3PL resources, processes and generate new model.

\section{Literature Review}

The 3PL service providers have several services as executed, these are cross-docking, transportation, packaging, warehousing and freight forwarding (Gudehus and Kotzab, 2012). Some of additional services in 3PLs are the container yards, block trains services (BTS), cargo insurance, customs clearance, container repairs, heavy machinery rentals, consolidation and break bulking activities (Omotayo, Sabar and Melan, 2017). As established in the literature, the issue of 3PLs performance and logistics services is very important at these present competitive businesses (Wang, Jie, and Abareshi, 2015). Likewise, the general logistics in courier services was popular, important and engaged with a big number of stakeholders as well as customers (Zahid, Sabar and Melan 2019).

As established by Lai, Ngai and Cheng, (2004) it is compulsory of logistics and transport service providers to create value-added services when executing deliveries. Predominantly, the 3PLs service providers were exhibit a noteworthy role in logistics and supply chain service in goods deliveries. Also, it connected with several business partners and combined in a chain of logistics which significantly influencing on the performance of 3PLs. Likewise, performance of logistics is a pivot success for the 3PLs service provider and their customers. The reason for this is that, the 3PLs and transport service providers are impacted by the performance of logistics, possibility of other stakeholders in competing the business and securing customers on the logistics chain field and facing the negative impact of logistics performance. On the other hand, performance measurement is expressed as an indicator of the work executed and the result of its operations, process or entity of the organization (Cohen and Roussel, 2005). In many cases, the main peculiar factor for the choice of 3PLs service provider is the logistics (Hassan, Razali, \& Talib, 2015; Ho, He, Lee, \& Emrouznejad, 2012; Thai, 2013). In line with the expansion of the services and manufacturing sectors in Malaysia and Thailand a specific model in 3PLs is required to be developed with the following Nine (9) segmentations.

\section{A. Operational Model}

An operating model is both an abstract and visual representation (model) of how an organization delivers value to its customers or beneficiaries as well as how an organization actually runs itself. The long-term growth and financial wealth of 3PL organization is its sales. Wong and Karia (2010) explaining the Competitive Advantage of Logistics Service Providers more on Resource-Based and view approach. A good designed logistics services that is efficient and combined with good management and provision of series of high-quality customer services which are critical to the third-party logistics success (Yong Lin \& Pekkarinen, 2011). In a normal situation, the 3PL sales process involves several phases and relies on the company size which is an indication of delegation of responsibilities. The model, in accordance with the practices of International 3PL's market, takes a foresight into sales forces allocation to some responsibilities such as marketing and indoor sales and field sales. In the sphere of this model, there is an assumption that employees are accorded divers kind of activities. A business operating model is the combination of roles, skills, structures, processes, assets and technologies that allow an organisation to deliver on its strategy. In effect, it is the way the business is set up to achieve its goals and meet future challenges (Bevington group, 2020)

The operational activities of the 3PL service provider's development strategy relies on the resources that manage by the organization. Cheng, Hua and Zheng (2009) promulgated a structural model called hierarchical interpretive structural model based on the modern and future success factors of 3PL organizations. Gudehus and Kotzab (2012) referring to Comprehensive logistics and contemporarily, corporate system, internal integration and customer service are viewed as equal and useful factors for the success of 3PLs. Although, in view of the future trends, conclusion can be made that corporate system backed by innovation will bring about success for 3PLs organization. In the study conducted by Wong and Karia (2010) revealed on the content analysis in some leading 3PLs service provider was done in different types of resources and characteristics. The types of resources with their characteristics were identified such as human, information, relational, knowledge and physical. Abidin, Abdullah, Hassan, and Sobry, 2016 and Jalil, Prapinit, Melan, and Mustaffa, 2019 revealed on adoption of business intelligence, technological, individual and supply chain efficiency. The resource-based view (RBV) proclaims that market orientation can help companies to enhance the performance (Barney, 1991). Hence, market orientation is an asset that provides a competitive advantage to the companies. Ellinger et al. (2008) 
investigated how market orientation and employee development practices in 3PL companies are influencing for both employee and organizational performance. Lagoudis and Shakri (2015) referring on a framework for Measuring Carbon Emissions for Inbound Transportation and Distribution Networks. Kotlars (2018) revealed on the resources on 3PL and processes personnel, time capacity, suppliers, customers, finances and Brand. He also suggests on the process towards personnel management, commercial activities, procurement, operations and administration. He added on the actions towards the efficiency of sales, marketing personnel, operational personnel, administrative, procurement, suppliers, commercial process, financial performance and customers.

\section{B. Commercial activities model}

Some of personnel are involved in commercial or sales operations and processes that are also divided into various phases. Sales forces availability is expressed by "Sales and marketing capacity" and measured in man hours. Sales process commences with initial 'customer contacts. Field sales personnel ability is expressed by 'Monthly Field sales norm per full time employee'. This indicator reflects single salespersons' ability to focus new possible customers on the basis of monthly payment. Customers' contacts are transformed to 'Customer response', the indicator that is usually impacted by the degree of recognition of 3PL companies and their reputation in the marketplace. These factors are amassed into 'Brand equity" with indicator showing as 'Brand awareness', 'Customer loyalty' and 'word of mouth' factors (Crescitelli and Figueiredo, 2009; Leone et al., 2006; Tolba and Hassan, 2009). Thereafter 'Customer response' is altered to 'Customer requests for proposals'. The statistical data of 3PL companies are utilized to explain this rate of transformation and the quantity of orders of single customers. In this model, customers' orders are assessed in "file" units. The requests for proposals are transform into customers' orders, such indicators as "indoor sales monthly norm per full time employee" is employed. This is replica to 'Field sales monthly norm per full time employee' expressed by industry and companies' standards. Every company should write down its fundamental approach to going to market and how it will create real value for customers, employees, and even partners. This is why business models typically include information about target customers, the market, organization strengths and challenges, essential elements of the product, and how it will be sold. Business models are the fastest way to capture and communicate these elements within a company. Tufail, Ibrahim, Melan and Nawi, (2019) discussing on the novel approach of quantifying energy security in terms of economic, environmental and supply risk factors.

Here is a detailed list of components that are found in most business models (Road mapping 2020) discusses on problem the target customers' pain points referring to the solution on how the company intends to meet the customers' needs. The Key Resources refers on physical, intellectual, human, and financial assets at the company. Other than that he also discusses on Customer Segments who are the target customers, Unique Value Proposition, customers and solution. The Competitive Landscape on what alternatives can customers use. The second point he discusses on Competitive Advantage is the characteristics not easily copied or bought elsewhere sales channels on how the company will reach customers. Revenue Streams revealed on how the company generates income. The third point he also discusses on the revenue model, framework for how the company will be profitable. Key Partners refers to the partners and suppliers essential to the business. The Cost Structure includes on what are the company's costs and how should that affect pricing and Key Metrics discusses on how the company measures success.

\section{Administrative model}

Relative to international 3PL practice, administrative operations linked to activities and sales stand beside the usual processes as they focused the formation of specialization of personnel to subsequently raise the efficiency of general personnel. Meidute-Kavaliauskiene, Aranski, and Litvinenko (2013) discusses on the consumer satisfaction with the quality of Logistics Services. Two major operations of administrative personnel involved customers and supplier's administration. In reference to the supplier management, it is reproduced as a stock of 'Accumulated supplier invoices' which is equivalent of 'completed orders' whereby transportation units were retained from suppliers. Meanwhile invoice received are either paid, which is recorded as 'Paid supplier invoices', or rejected, known as 'Rejected supplier invoices. Barney, J. (1991) discusses on the Firm resources and Sustained Competitive Advantage. In term of customer management, two stocks are revealing, these are 'Customer invoices in preparation', these are not yet issued, therefore, the payment for these services are not expected by the company. The 'issued customer invoices' flow is expressed by handiness of administrative resources ('Customer administration') over a certain period of time. Meanwhile, 'Pending payments from customers' are belated invoices that the are expected to be paid by the company considering 'Customers payment terms', this is expressed as periods for delay function in 'Received payments' flow. Shin and Thai (2016) discusses on the study of the influence of sustainable management activities on customer satisfaction and long-term orientation in the shipping industry. 


\section{Personnel Management model}

Cheng, Hua and Zheng (2009) discuss on the Success Factors for Third-Party Private Logistics Enterprise in the Past and Future is based on personnel management quality. The major 3PL resource considered is the personnel. The initial employees' number is expressed as the starting point of the model. The 'current employees' stock is inbound regulated, that is 'New-coming employees' and outbound employees, which is the 'Leaving employee' flows. In the model, the necessity of 'General personnel decreases' and 'General personnel increase' is explained by current 'Personnel productivity' that is compared to industry and company standards or 'Desired personnel productivity'. This overall indicator is conformed of four different indicators revealing particular 3PL efficiency operations whereby individual personnel are earmarked. Liu and Lyons (2011) revealed on the analysis of Third-Party Logistics Performance and Service Provision. 'Expected order fulfilment ratio is explained by the company and standards of competition. There is efficiency of administrative personnel and its' defined by two factors. Capacity to cover the needs of customers needs is the major purpose of 3PLs procurement personnel. Meanwhile the 'Sales and marketing personnel efficiency' is evaluated by 'sales success ratio'. Ellinger, Ketchen Jr., Hult, Elmadağ and Richey Jr (2008) referring on the Market Orientation, Employee Development Practices, and Performance in Logistics Service Provider Firms and Industrial Marketing Management are also referred on the requirement in personnel management obtaining various information and data towards present and potential customers.

\section{E. Procurement}

The productivity of services by labour is far lagging behind organization. Procurement personnel efficiency is evaluated by comparing the contractual purchased material with expected capacity coverage (Lagoudis \& Shakri, 2015). Acknowledge that the key responsibility of sales personnel is new a business attraction. A good suggestion is to examine alternatives contexts of implementation of lean methodology in supply chain management and logistics in order to acknowledge and side-line on the differential means of engaging the lean method in delivery of services. Ho and Emrouznejad (2012) discusses on the Strategic logistics outsourcing. Another important aspect in procurement which is relevant is how to realize the characteristics means of adopting the system and personnel between company and customers. Jalil, Prapinit, Melan and Mustaffa (2019) revealed on the adoption of business intelligence, technological, individual and supply chain efficiency for the purpose of facilities to be equipped for the personnel such as IT, education, software and the systems related.

The protagonist of various perspective of quality of service in certain organization has been emphasised by different researchers as well as experts (Akanmu, Hassan and Bahaudin, 2020; Meidutè-Kavaliauskienè, Aranskis, and Litvinenko, 2014; Shin and Thai, 2016). Lean management and productivity are few of the main proportion as top criteria relied on different measures such as cost, responsiveness and assurance. Rajesh, R., Pugazhendhi, S., Ganesh, K., Ducq, Y., \& Lenny Koh, S. C. (2012) discusses on the Generic Balanced Scorecard Framework for Third Party Logistics Service Provider which referring the personnel responsibility monitoring the contracts management with appropriate ways. Hassan, Hussain, and Rahman, 2020 and Omotayo, and Melan, 2017 had discussed on factors influencing the information and communication technology (ICT) of third party logistics. Therefore, the BSC idea consists of main strategies for all main functions and 3PL organizations' department. The operations and management of 3PLs organization are well connected to human resources management, organization structure, operations and marketing. The service production procedures were investigated by Leem and Yi (2009) and proposed a system of assessing 3PL management efficiency utilizing on the data envelope analysis (DEA).

\section{F. The 3PLs' Quality Management model}

TQM is a management philosophy that seeks to integrate all organizational functions (marketing, finance, design, engineering, and production, customer service, etc.) to focus on meeting customer needs and organizational objectives. Khurram Hashmi (2012) discusses on the total quality management and implementation. It maintains that organizations must strive to continuously improve these processes by incorporating the knowledge and experiences of workers. Thai (2013) revealed on the Logistics service quality towards the conceptual model and empirical evidence. Originally applied to manufacturing operations, and for a number of years only used in that area, TQM is now becoming recognized as a generic management tool, just as applicable in service and public sector organizations. Domingues, M. L., Reis, V., \& Macário, R. (2015). A comprehensive framework for measuring performance in a third-party logistics provider The system of internal performance evaluation which consists of indexes classified as first class are quality and flexibility, logistics costs, productivity, level of customers' service, assets and financial affairs. Quality Management Principles 
(2015) The eight principles in Quality Management Principles are focusing on Customer focus, Leadership, Involvement of people, Process approach, System approach to management, Continuous improvement, Factual approach to decision making, Mutually beneficial supplier relationships and Resources Model.

\section{G. Performance Measurement}

In competition environment, related measurement in performance has confirmed to be a break-even tool and attain objectives of the businesses. Wang, Jie and Abareshi(2015). Business logistics performance measurement in third-party logistics: an empirical analysis of Australian courier firms. The system of performance measurement is outlines that assimilate with several information performances such as KPI, which is interpreted as key performance indicators, systematic and accessible way (Domingues, Reis \& Macário, 2015). The systems of performance measurement offer the organization with tools that is needed to monitor, planning and support operational processes (Liu and Lyons, 2011). Performance evaluation is also important in resources control in organization. A logical structure is needed to evaluate the factors of performance of 3PL service providers from the point of view of management. Kayakutlu and Buyukozkan (2011) revealed on the advance model to detail the efficiency of drivers that connected to the operational and strategical goals of 3PL service providers. The models consist of Four (4) dimensions, which are; performance attributes, logistics operations, planning operations and performance targets. Zhao, Ding and Liu (2007), propound on a system of two-dimensional index of the performance evaluation for the 3PLs service providers for evaluating external and internal environment of organization. Jothimani and Sarmah (2014). Supply Chain Performance Measurement for Third Party Logistics. Benchmarking: The logic of external performance appraisal in using index system which involves with the level of customers' satisfaction, comprising supply price, information exchange, service level and supply time.

Kayakutlu and Buyukozkan (2011) revealed on the three targets related to performance and highlighted as accredited customers, capital balancing and alliance network. The planning process consists of information strategies and resources. Prapinit, Sabar and Melan (2019) revealed on the demand for Logistics Management Studies for better and knowledgeable of personnel dealing with daily jobs. Inside 3PLs framework, the logistics operations comprise of management for customer relations, demand coordination, inventory management and transportation management (Omotayo and Melan (2017). Every logistics activity is assessed by some standards of its performance, for example, management of relation management is evaluated with the focus on such factors as request trends, portfolio change, order cycle, order frequency and complain rate. In the study conducted by Jothimani and Sarmah (2014) on advances application of SCOR, (Supply Chain Operations Reference) model and multi-criteria methods of decision-making methods to recognise 3PLs' KPI organizations and measure 3PL organizations' supply chain performance, also, recognizes customer-related and internal factors for assessing performance (Prapinit, Sabar and Melan (2019). The model includes Five (5) major processes (Plan, Make, Deliver, Source and Return) and its' intended into 3 categories of procedure details. Jothimani and Sarmah (2014) showed on the performance measurement systems are useful instrument for the success evaluation of 3PL organization and acknowledge corrective measures on the failure of service. The history of key strategy engagement by 3PL organization has included the endeavour to acquire the largest market share. Hence, it is important to comprehend trade-offs and interrelationships between alternative company on performance dimensions. Rajesh et al. (2012) proposed the engagement in applying balanced scorecard (BSC) that involves on the use of performance metrics from different perspectives such as growth, internal processes, customers and finances.

\section{H. Financial model}

The recognition of the financial block in the overall model permits assessment of the real influence maximisation of processes and resources of 3PL on financial resources. 'Bank account cash flow' is germane base on 3PL essential corporate environment and business. Bank account cash flow has two inbound and three outbound flows. Kayakutlu and Buyukozkan (2011). Assessing Performance Factors for a 3PL in a Value Chain and also refers on the flow from Payment from customers includes regular payments for completed customers' orders and credit flow is accumulated of Bank credit and shareholder credit. Leem and Yi (2009) revealed on the Measurement on the management efficiency of Korean 3PL Providers with special financial measurements. Fundamentally, the two flows add to cash inflow. As per the business of 3PL, most portion of Regular payment flow is completed by Payments to subcontractors. A credit payment which consists of shareholders' credit and bank credit, make up the second portion of 'Regular payments' flow. Labour payments involves Fixed payments to personnel namely sum of monthly sales, operational costs, administrative and procurement, and 'variable payments of personnel' that is estimated as monthly percentage 'Commercial margin'. Cheng, Hua and Zheng (2009) discuses on the success factors for third-party logistics in the past and future which based on financial 
performance. The key notion for the actualization of this bonus system is stimulated of personnel to attract and engender business that is profitable with margin that commensurate to company's targeted budget. Lai, Ngai and Cheng (2004) revealed on an empirical study of supply chain performance in transport logistics. Although 3PL is commonly acknowledged as a light-asset business, there is investment to assets flow that accomplish as fixed assets stock. The company outlines Asset investment ratio to endure the required stock of technology and equipment. Zhao, Ding, and Liu (2007) are referring on research on performance evaluation of logistics service based on SCM which is relate to financial model.

\section{Results and Discussion}

\subsection{The Final Model Suggested}

There were several mechanisms applied during the process in developing a new model for the 3PL. This research involved literature reviews and the related studies which confirmed to be the preeminent of its processes. The methodology of this research is based on selected several research which focusing on the system dynamics, performance measurement, quality, resources and business performance of present 3PL. There were several mechanisms as proposed by researchers through literature and taken into consideration in developing new a model of 3PL. Using a free selection process which considered the best of observation as chosen from the various researchers and reviews critically on several literatures were selected in the new model. At the end, this new suggestion to the model found out and it comprises of Nine (9) segmentations, which are Operations, Commercial activities, Administration, Personnel Management, Procurement, Quality Management, Resources, Performance Measurement and Financial models. The model is indicating in all areas of activities of 3PL service providers as suggested by the researchers. This study proposes a new model for Third-party Logistics (3PL) performance indicators for future guidelines in related industry. The new model is proposed to be the better concept in service providers which are focusing on 3PL Business Model in future endeavour. This is illustrated in Figure 1.

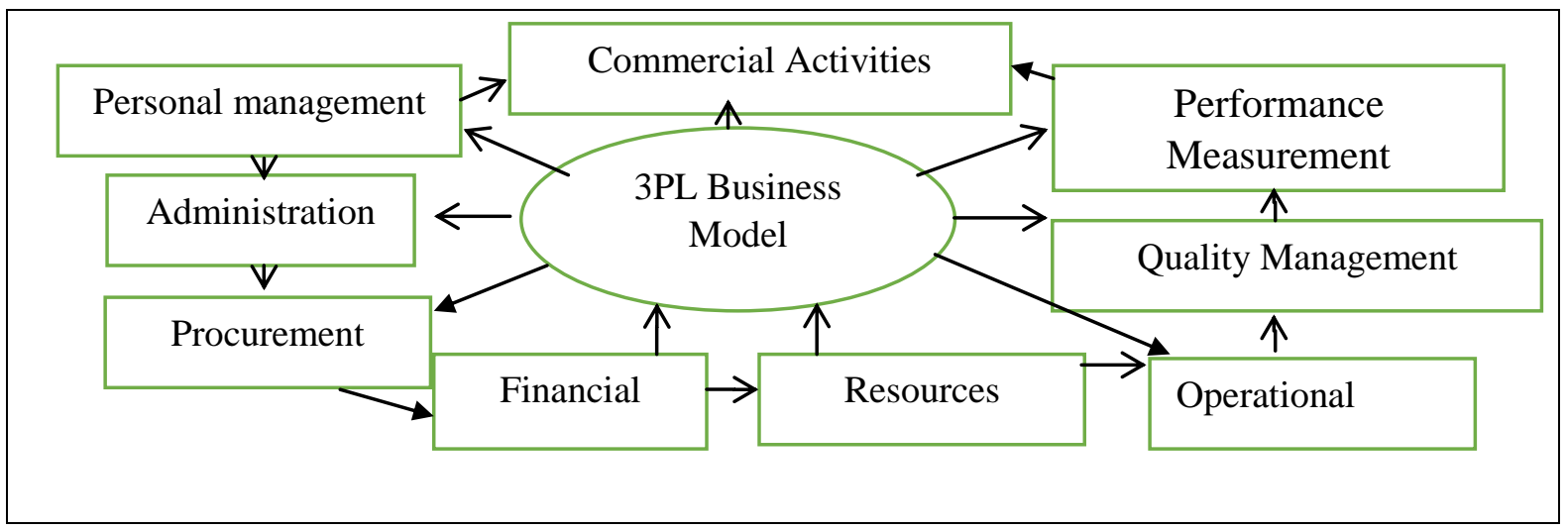

Figure 1. New Model of 3PLs Business Model (2020)

\section{Conclusion}

In summary, the overall findings had connected with the literature reviews and suggested by several authors. The authors mentioned of theory of resource-based and observed by the most of their research in the overall write up in this study. This 3PL business model was the contribution of new knowledge of the study and it is essential to enhance competitive advantage on the evaluation process especially on the performance in future service industry. In some recent studies, focus is on knowledge-based logistics services, whereby personnel management are focuses as the main current 3PL Business model. On the other hand, Operations, performance measurement, personal management and procurement had the direct impact on the new 3PL business model. Some major stakeholders in the field of logistics are of the same opinions that the value-added services such as quality management should replace as one of logistics functions in the model. The related articles in the literatures expressed on the new 3PL business model in the commercial organization. All related processes in the model are integrated among others for better interaction. Further study can be conducted to improve on the general model of 3PL resources and processes. This is challenging to see organizations are functioning differently without any external disturbance and environmental factors. Further research is necessary to enhance on the current model may be suit with the current practices. It is difficult to justify on the company is functioning 
without the influence of external environments. Hence, further investigation and development of model important in the Third Party's Logistics Providers for future studies.

\section{References}

1. Abidin, R., Abdullah, R., Hassan, M. G., \& Sobry, S. C. (2016). Environmental sustainability performance: The influence of supplier and customer integration. Social Sciences (Pakistan), 11(11), 2673-2678. Retrieved from www.scopus.com

2. Akanmu, M. D., Hassan, M. G., \& Bahaudin, A. Y. B. (2020). A preliminary analysis modeling of the relationship between quality management practices and sustainable performance. Quality Management Journal, 27(1), 37-61. doi:10.1080/10686967. 2019.1689800

3. Barney, J. (1991), Firm Resources and Sustained Competitive Advantage, Journal of Management, 17(1), 99- 120. https://doi.org/10.1177/014920639101700108

4. Bevingtongroup (2020) Operation Model in developing countries on operating and service https://www.bevingtongroup.com/services(Jalil, Prapinit, Melan, \& Mustaffa, 2019)/ operating-model-design

5. Cheng, L., Hua, M., \& Zheng, L. (2009). Success Factors for Third-Party Private Logistics Enterprise in the Past and Future. International Conference on Management of e-Commerce and e-Government, Nanchang, China, 306-309. https://doi.org/10.1109/ICMeCG.2009.112

6. Cohen, S., \& Roussel, J. (2005). Strategic supply chain management: the five disciplines for top performance. McGraw-Hill.

7. Crescitelli \& Figueiredo (2009) Brand equity evolution: A system dynamics model, Brazilian Academic Reviews, Vol. 6 No. 2

8. Domingues, M. L., Reis, V., \& Macário, R. (2015). A comprehensive framework for measuring performance in a third-party logistics provider. Transportation Research Procedia, 10, 662-672.

9. Ellinger, A. E., Ketchen Jr., D. J., Hult, G. T. M., Elmadağ, A. B., \& Richey Jr., R. G. (2008). Market Orientation, Employee Development Practices, and Performance in Logistics Service Provider Firms. Industrial Marketing Management, 37(4), 353-366. https://doi.org/10.1016/j.indmarman.2007.01.002

10. Gudehus, T., \& Kotzab, H. (2012). Comprehensive logistics. Springer Science \& Business Media.

11. Hassan, M. G., Hussain, F., \& Rahman, M. B. S. (2013). Exploring usefulness of CRM and it in malaysian hotel industry: A qualitative approach. Journal of Information and Communication Technology, 12(1), 21-37. Retrieved from www.scopus.com

12. Hassan, M. G., Razali, M. R., \& Talib, A. N. A. (2015). Industrial supplier-manufacturer relationship and environmental dynamism on strategic outsourcing success: A conceptual study. Jurnal Teknologi, 74(1), 35-42. doi:10.11113/jt.v74.3345

13. Ho, W., He, T., Lee, C. K. M., \& Emrouznejad, A. (2012). Strategic logistics outsourcing: An integrated QFD and fuzzy AHP approach. Expert Systems with Applications, 39(12), 10841-10850.

14. Jalil, N. A., Prapinit, P., Melan, M., \& Mustaffa, A. B. (2019). Adoption of business intelligence technological, individual and supply chain efficiency. Paper presented at the Proceedings - 2019 International Conference on Machine Learning, Big Data and Business Intelligence, MLBDBI 2019, 67-73

15. Jothimani, D., \& Sarmah, S. P. (2014). Supply Chain Performance Measurement for Third Party Logistics. Benchmarking: An International Journal, 21(6), 944-963. https://doi.org/10.1108/BIJ-092012-0064

16. Jothimani and Sarmah (2014) on Advances application of SCOR, (Supply Chain Operations Reference) model and multi-criteria methods of decision-making methods

17. Kayakutlu, G., \& Buyukozkan, G. (2011). Assessing Performance Factors for a 3PL in a Value Chain. International Journal of Production Economics, 131(2), 441-452. https://doi.org/10.1016/j.ijpe.2010.12.019

18. Khurram Hashmi (2012) Total Quality Management for Industry as a culture, https://www.isixsigma.com/methodology/total-quality-management-tqm/introduction -andimplementation-total-quality-management-tqm.

19. Lagoudis, I. N., \& Shakri, A. R. (2015). A Framework for Measuring Carbon Emissions for Inbound Transportation and Distribution Networks. Research in Transportation Business and Management, 17, 53- 64. https://doi.org/10.1016/j.rtbm.2015.11.001

20. Lai, K. H., Ngai, E. W. T., \& Cheng, T. C. E. (2004). An empirical study of supply chain performance in transport logistics. International journal of Production economics, 87(3), 321-331.

21. Leem, B., \& Yi, S. (2009). Measuring the Management Efficiency of Korean 3PL Providers with Financial Measurements. PICMET: Portland International Center for Management of Engineering and 
Awoyemi Adebare Omotayo, Mustakim Melan, Zulkufli Aziz, Pichit Prapinit, Patchateeya Boonyarit, Mohamad Ghozali Hassan

Technology Proceedings, 2-6 August, 2009, Portland, OR, USA, 1221-1224. https://doi.org/10.1109/PICMET.2009.5262018

22. Leone et al., (2006) Linking Brand Equityto Customer Equity, Journal of Service Research, Volume, 9, No. 2, Sage Publications.

23. Liu, C., \& Lyons, A. C. (2011). An Analysis of Third-Party Logistics Performance and Service Provision. Transportation Research Part E: Logistics and Transportation Review, 47(4), 547-570. https://doi.org/10.1016/j.tre.2010.11.012

24. Meidutè-Kavaliauskienè, I., Aranski, A., \& Litvinenko, M. (2013). Consumer Satisfaction with the Quality of Logistics Services. Contemporary Issues in Business, Management and Education 2013. Procedia - Social and Behavioral Sciences, $110 \quad$ (2014), 330-340. https://doi.org/10.1016/j.sbspro.2013.12.877

25. Omotayo, A., \& Melan, M. (2017). Factors influencing the information and communication technology (ICT) of third party logistics in Malaysia. International Journal of Supply Chain Management, 6(2), 202-208.

26. Prapinit,P., Sabar,R., Melan, M. (2019) Demand for Logistics Management Studies in North Eastern Thailand International Journal of Supply Chain Management, Vol 8, No 5. Quality Management Principles (2015) The eight principles in Quality Management/Principles https://www.pilgrimquality.com/blog/iso90012015-quality-mgmt-principles

27. Rajesh, R., Pugazhendhi, S., Ganesh, K., Ducq, Y., \& Lenny Koh, S. C. (2012). Generic Balanced Scorecard Framework for Third Party Logistics Service Provider. International Journal of Production Economics, 140(1), 269-282. https://doi.org/10.1016/j.ijpe.2012.01.040

28. Road mapping (2020) Business model for the business in developed countries business-model. https://www.aha.io/roadmapping/guide/product-strategy/what-are-some-examples-o-

29. Shin, Y., \& Thai, V. V. (2016). A Study of the Influence of Sustainable Management Activities on Customer Satisfaction and Long-Term Orientation in the Shipping Industry: Evidence from Users of Korean Flagged Shipping Service. International Journal of Shipping and Transport Logistics, 8(1), 120. https://doi.org/10.1504/IJSTL.2016. 073312

30. Tolba \& Hassan (2009) Linking customer-based brand equity with brand market performance: A managerial approach, Journal of Product \& Brand Management 18(5):356-366,

31. Tufail, M. M. B., Ibrahim, J. A., Melan, M., \& Nawi, M. N. M. (2019). Novel approach of quantifying energy security in terms of economic, environmental and supply risk factors. Journal of Advanced Research in Fluid Mechanics and Thermal Sciences, 57(1), 100-109

32. Thai, V. V. (2013). Logistics service quality: conceptual model and empirical evidence. International Journal of Logistics Research and Applications, 16(2), 114-131.

33. Wang, M., Jie, F., \& Abareshi, A. (2015). Business logistics performance measurement in third-party logistics: an empirical analysis of Australian courier firms. International Journal of Business and Information, 10(3).

34. Wong, C., \& Karia, N. (2010). Explaining the Competitive Advantage of Logistics Service Providers: A Resource-Based View Approach. International Journal of Production Economics, 128(1), 51-67. https://doi.org/10.1016/j.ijpe.2009.08.026

35. Yong Lin, Saara Pekkarinen (2011) Journal of Business \& Industrial Marketing, Emerald Insight ISSN: 0885-8624

36. Zahid, M. M., Sabar, R., Melan, M., (2019) Effectiveness on Drop Trailer Method (DTM) of Haulage Industry in Malaysia, International Journal of Supply Chain Management Vol 8, No 5.

37. Zhao, Q., Ding, H., \& Liu, H. (2007). Research on Performance Evaluation of Logistics Service Based on SCM. Proceedings - ICSSSM'06: 2006 International Conference on Service Systems and Service Management, 2, 984-989. https://doi.org/10.1109/ICSSSM. 2006.320778 